\section{MEDICAL NOTES ON MONTENEGRO.}

Oscar L. Levy, BY

M.D., L.R.C.P., M.R.C.S., and

J. C. F. NaUmanN, M.D., L.R.C.P., M.R.C.S.

THERE are in the world not a few forgotten corners. Such is Montenegro, a country, however, full of interest to the archæologist, the ethnologist, and the linguist. To mention only two or three particulars: For the first there is the old Roman ruin of Dioclea, while to the province of ethnology and philology pertains the fact that the people of Montenegro, while belonging to the Southern Slavs, yet differ from them in many points, as do the Albanians. Then, for the student of folklore, there are their strange Christmas customs and the songs of the Montenegrin bards, who to the accompaniment of their "Guslas" celebrate the achievements of their compatriots in their wars against the Turks. For the geographer and explorer there are the untrodden wastes of the Black Mountains - deserts which as yet Cook's and Stange's tourist parties have not invaded. At present, however, we wish to confine our remarks to matters of special interest to the medical profession.

In Cettinje, the capital, there is a small hospital, built as have been many other public edifices in the country, with Russian money. We saw in this hospital a splendid outfit, presented very lately by the Russian Government, consisting of excellent surgical instruments, dressings, and ambulance tents; these were sent at the same time as the famous 30,000 rifles. The hospital stands in the north-east of the small town, close to the great limestone wall, which surrounds the dreary punchbowl-like hollow of Cettinje on all sides. It consists of two separate buildings ; the larger one contains about 20 beds, while the smaller contains the operation room. To Dr. Theodor Perazié, formerly a military surgeon in the Austrian service, its amiable head-physician, we are indebted for some of the following facts :

From the geographical, and consequently from the medical, point of view, the country must be divided into two different parts of unequal size. The first is very much the larger, and contains all the mountainous districts ; the second and smaller includes the fertile plains of Montenegro, the valleys of the Tsherniza, Rieka, and Zeta-Moracza rivers. All these rivers flow into the lake of Skutari, which is situated on the border between Montenegro and Albania, in a tract of country very swampy in, its upper part. Geologists point out that formerly the lake extended much further, but that it has fallen considerably, leaving the swamps behind it. Malaria is of course rife here, and we saw several typical cases of this disease, with enormous spleens. The rigour and humidity of the climate of the monntainous parts of the country, the western Montenegro as well as the eastern Berda, is entirely different from the south-Italian climate in the plains, and this accounts for the frequent occurrence of rheumatism, both articular and muscular. Conjunctivitis and other eye troubles are very frequent. Their cause becomes very well known to the traveller obliged to stay for even a single night in one of their houses. These houses are, according to our ideas, very imperfect ; they have no chimney, except the Prince's palace, a fire is kept always burning, and coffee prepared on the bare ground, the smoke finding an exit from the room through the windows, which afford abundant ventilation, for they never shut properly. When the much-dreaded Bora wind sweeps down the country the draught enters through the windows, and through the walls also, for the limestone blocks of which they are made are put together without mortar.

Throughout the country consumption is common, a fact which is surprising in a mountainous district. Dr. Perazié performs many resections for tuberculosis, but amputations are never allowed, a prejudice we met with all over the near East, alike among Jews, Christians, and Mohammedans. Dr. Perazié was justly proud of two successful cases of cataract operation in old men, who gratefully kissed the hem of his coat when we passed through the ward. One of them was brought down from the mountains by his wife, who dragged him after her with a cord. Their march down to the capital took a fortnight. The little hospital at Cettinje is the last place of resort for Montenegrin patients.

The men of the Tsernagora are well built, seldom stout, and mostly over 6 feet high (Fig. 1). We had never seen such broad-chested people. except some Circassians whom we met with in the Caucasus last year. It is easily to be understood that their wounds heal very readily. It was said by surgeons during the late war with Turkey that a man who did not die before he got to the hospital has nineteen chances in twenty of getting well. Plenty of people go about bearing in them bullets received in war and in peace, or what is called peace here ; for the Montenegrin clans still have their blood feuds among themselves, as well as with the neighbouring Albanian tribes of Turkey. Everybody, from the prince down to the postoffice clerk and schoolmaster, carries a pistol, and these weapons sometimes go off of their own accord. We saw in the hospital a Montenegrin thus shot in the thigh, and an Albanian with a bullet in his left pleural cavity. The semicivilised mountaineers, like those of Kurdestan, the Libanon, the Khyber Passes, shun of course trade and agriculthan the only one suitable to a gentleman. All their work they leave to the women, able to a gentleman. All their work they leave to the women, They have a proverb amongst them, that a good woman is worth two oxen, which may remind us of Homer's words:

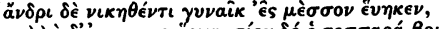

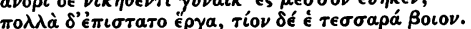

$$
\begin{aligned}
& \text { For him, who fell } \\
& \text { A damsel, in their midst display'd, well skilled }
\end{aligned}
$$$$
\text { In divers arts, and priced at oxen four. }
$$$$
\text { (Iliad, lib. xxiii, 704.) }
$$

But the women are very small; in fact they look real pygmies compared with the men, a fact deserving the attention of the anthropologist. Although they are pretty when young, they soon show the advance of age. Childbirth, 
according to good authority, is always easy ; the forceps has never been used in the country. The woman is delivered standing, the legs apart, and leaning over a chairor another piece of furniture. The cord is usually not cut vefore the placenta is expelled, and is then severen very near the placenta, three knots being made on the side of the child. The cord is thus preserved in its whole length until it separates. The women go to work the day after delivery, either from pride or necessity. A fortnight after birtl the children are baptised according to the Greek Orthodox rite. They are wholly dipped in a great basin of water. This is probably the only bath they take during life. Skin diseases therefore abound, more especially those caused by external parasites, vegetable (herpes tonsurans, favus), and animal (pediculi, scabies). The latter they cure by a popular remedy, which consists in smearing some of the tobacco juice out of their long Turkish pipes, the tshibouks, over the affected part. Rather more romantic is the cure of ear troubles ; the horn of an ox is put over the bad ear, and then the "doctor" sucks out the air through the perforated end till he and the patient hear a distinct noise.

Syphilis is not uncommon amongst them. It has been imported by returning emigrants, for many Montenegrins go to Stamboul as well as to the West, where they become, as an old Turk once said of the Ottoman young men sent to Europe to be educated, not civilised but syphilised.

As in other mountainous countries, people of the same valley intermarry frequently, and cretinism is found in Montenegro to some extent. The accompanying photograph (Fig. 2) shows a case. Goitre is common only in one eastern valley, called the Wassojevitch district.

For medical and sanitary purposes, the country is divided into seven districts: (I) Cettinje, (2) Niksitch, (3) Podgoritza, (4) AndricvitzaKolachine, (5) Dulcigno, (6) Antivari, (7) Rieka. There are three medical men in Cettinje, including our courteous friend and the military surgeon; one is at Niksitch, and one at Podgoritza. They have all studied in Russia At each of the other districts is a medical practitioner, 'who has similarly pursued his studies,

but possesses no diploma, with the exception of Rieka, where the medisal practitioner is also a chemist. It consequently did not surprise us to be consulted wherever we went.

In Cettinje we we at once sent for to attend a famous Montenegrin " Woivoda," Peko Pawlowitch, who had directed the Herzegovina insurrection against Turkey, and had vanquished the enemy in several battles. $\mathrm{He}$ was alluded to by correspondents in the last war as the terrible Peko, because he once took his meal in the midst of fifty Turkish heads, which he had cut off and which he had placed on sticks. (This custom is still a feature of Montenegrin warfare).

We found lying in bed a fine old man of 83 , of noble and courteous manners, who shook our hands heartily-the very picture of E. About's Roi des Montagnes. He had been in bed for five years, suffering from headache, and was totally paralysed and blind. The cause of the blindness was cataract; the left eye had been operated upon, but without success, the cornea showing a deep, cloudy scar.

Diring our ride through the country, which we left by way of the passes of Duga, where many a good Turk and Montenegrin has seen his last day, many came to ask our advice, from Ministers of State down to shepherds, and sometimes quite a swarm of people accompanied us, wishing to be examined at our next halting place. When we had arrived there, and the people had said that we were doctors, the host, who generally was the head of the clan, would put his hands to his mouth in form of a trumpet, and sing out the news in long-drawn tones, asking all the sick to come up. This vocal telegraph of the Montenegrlns is more effective than the ordinary, and in case of war the whole country can thus be roused up in a few hours.

Gerur UNiversirima Recent statistics state that the number of students attending the universities in Germany is now 32,241 , an increase of 1,311 on last year. Berlin heads the list of twenty-one universities with 4,882 students, and is followed by Munich with 4,028 , Leipzig 3,174 , Bonn I,975, Halle 1,604 , Breslau 1,587 , Freiburg 1,545 , Heidelberg 1,384 , Tübingen 1,377, Würzburg 1,312, Göttingen 1,216, Marburg 1, 115; Erlangen 1,070, Strassburg I,040, Greifswald 864, Kiel 838, Jena 755, Königsberg 733 , Giessen 733 , Münster 537 , and Rostock 462. In addition to these regular students, there are 5,445 students who have not matriculated, but who are entitled to attend the lectures in the various faculties. The number of medical students has risen from 8,633 to 8,692 . The most expensive universities in Germany are those of Heidelberg and Bonn ; the least expensive is Erlangen; but the average sum required for the support of a student at a German University is much less than it is in England. Including board, lodging, books, and college expenses, a German student, if he is fairly economical, can make a good appearance for less than $f 100$ a year.

Dr. W: W. Ireland has reprinted from the Proceedings of the Society of Antiquaries of Scotland, of which learned body he is a Fellow, some notes on the Scottish De Quencys of Fawside and Leuchars. The Quencys came from Normandy with Duke William, and the name is on the roll of Battle Abbey. A scion of the family found his way to Scotland in the time of King Malcolm IV, who made him a grant of land. After the time of Robert the Bruce, however, the name is no more heard of in Scotland. The family passed away without leaving a trace. None of the English De Quincys seemed to have gained rank in after-days, but there was Dr. Quincy who was eminent in the profession of medicine, and Thomas De Quincer who, besides his literary fame has a special interest for doctors as the most celebrated, if not the largest, of opium-eaters. His Confessions, with their highly imaginative descriptions of opium dreams, have probably been the means of introducing many to the "artificial paradise" which he paints in such glowing colours. 